\title{
The Functional Value of Proper Nouns in Medical Texts
}

\author{
Marianna Ohanyan \\ Yerevan State University
}

\begin{abstract}
Medical terminology is the professional language of those who are directly or indirectly engaged in the art of healing. Medical texts contain a lot of Greek and Latin borrowings, metaphoric usages of some terms and also term-eponyms. Health and care professionals need good communication skills to develop positive relationships and share information with people using linguistic varieties. Medical eponyms are often attached to the people who made the discovery. Term-eponyms can have both negative and positive overtones. They are a source of social communication and cognitively and culturally oriented. It can be stated that term-eponyms realize a cognitive function derived from the sphere they belong to.
\end{abstract}

Key words: medical discourse, medical terminology, term-eponyms, linguostylistic analysis, cognitive perceptions.

\section{Introduction}

Medicine is a sphere where the terms and terminological word-combinations are always in constant development. The use of eponyms fills the gap between different ethnic peculiarities in speech. An eponym is a term based on or derived from the name of a person. Eponyms are word units which fill some gaps in language, and some cognitive perceptions arise based on them which reflect the ethnic peculiarities of a world (Rilov 2006:298). In medicine, eponyms are the names of disorders linked to individuals who originally described the condition. They also help us remember and identify the disorder. For example, the Apgar score is a system for point score evaluation of the physical condition of a newborn after birth, named after Virginia Apgar (1909-1974), a New York anaesthesiologist. Some of the earliest uses of eponyms have been by ancient Greeks and ancient Romans. E.V. Bekisheva describes term-eponyms as the reflection of a person in medical terminology. Of importance are term-eponyms formed by means of proper nouns in combination with common nouns (Bekisheva 2007:25).

\section{The Functional Use of Term-Eponyms}

Medical terminology is a specialized language used by health care practitioners. And just like a foreign language it has its own vocabulary and acceptable ways of stringing words together. Medical language can be so different from common or general language that it would have to be acquired or learnt by language users with only general language knowledge. Medical terminology is a layer of lexical fund with the specific features, for in each professional sublanguage exists nomenclature vocabulary connected with certain realities and objects. Medical English in its broadest sense includes not only the official nomenclatures of the basic medical sciences (such as anatomy, biochemistry, pathology, and immunology) and the clinical specialties (such as pediatrics, dermatology, thoracic 
surgery, and psychiatry) but also a large body of less formal expressions, a sort of trade jargon used by physicians and their professional associates in speech, correspondence, and record-keeping.

At all periods of history, proper nouns denoting persons and places have been incorporated into adjectives, verbs, other nouns, and phrases, as in Jeffersonian, Americanize, Marxism, and Halley's comet. Eponymy, the derivation of words from personal names, has added to the medical vocabulary such diverse expressions as Addison's disease, chagoma, cushingoid, descemetocele, facies Hippocratica, galenical, and parkinsonism. Besides terms like these honoring distinguished physicians, others stand as monuments to important patients: bacitracin, an antibiotic named for Margaret Tracy, from whose tissues it was first isolated; Carriyn's disease (bartonellosis), named for Daniel A. Carriyn, a Peruvian student who inoculated himself experimentally with the disease and died of it; Hartnup disease, a heredofamilial metabolic disorder named for an English family of which several members were so affected; HeLa cells, a line of cultured human malignant cells named for Henrietta Lacks, from whose cervical carcinoma they are all descended; Legionnaires' disease, pneumonitis due to a bacterium of the genus Legionella, the disease and the genus both named for the American Legion, at whose convention in 1976 the first recognized outbreak occurred.

Names of prominent figures in myth, legend, and popular fiction have also found their way into the physician's lexicon. Atropine, a drug extracted from belladonna and various related plants of the genus Atropa and used as an antispasmodic for smooth muscle, is named, in allusion to its lethal properties, for Atropos, one of the three Fates, who was reputed to cut off each person's thread of life at the moment appointed for death. Morphine, a narcotic extracted from the juice of the poppy, is named for Morpheus, the god of sleep. Satyriasis, abnormal sexual excitability in the male, refers to the Satyrs, mythic sylvan deities with a leaning toward lechery. Pickwickian syndrome, extreme obesity with hypoventilation, refers to Joe the fat boy in Dickens's Pickwick Papers.

Most of the medical terms that incorporate geographic allusions are names of infectious diseases or their causative agents and refer to sites where these diseases are specially prevalent or endemic or where they were first identified or studied. In some of these terms, the names preserve their original form, as in Lyme disease, a tick-borne spirochetal infection named for a town in Connecticut, and Norwalk virus, which causes outbreaks of diarrhea in school children and is named after a city in Ohio. For other terms the geographic origins are not so evident: coxsackievirus, any of a group of human viruses causing various acute febrile syndromes, named for Coxsackie, New York; maduromycosis, a fungal skin disease, named after the city of Madura, India; tularemia, an infection of rodents sometimes transmitted to humans, first identified in Tulare County, California.

These terms based on proper nouns impart an element of novelty as well as a liberal dimension to what might otherwise be a depressingly prosaic assemblage of dry lexical bones gathered from the graveyard of dead languages. In a similar way, terms borrowed from modern foreign languages lend a cosmopolitan flavor to medical speech and writing. There are logical reasons why speakers of English customarily use foreign words for certain diseases, symptoms, or drugs. During the nineteenth century, the teachings and writings of Continental medical authorities played an essential part in the education of British and 
American physicians. Until World War I, Americans flocked to Paris and Vienna for specialty training, and brought back French and German words and phrases for which no English equivalents seemed quite right. Numerous French words continue in use today in clinical medicine (ballottement, "shaking", bruit, "noise", grand mal, "big disease", petit mal, "little disease"), surgery (bougie "dilator", curette, "scraper", "unbridling, cutting loose", rongeur, "gnawer"), and obstetrics (cerclage "encirclement", cul de sac "bottom of the bag", fourchette "little fork", souffle "blowing"). The suffix -ase, used to form the names of enzymes, first appeared in diastase, a French respelling of Greek diastasis, "separation". The sugar suffix -ose dates from French glucose, based on Greek gleukos, "sweet wine".

E.g. Asherman syndrome - a syndrome of intrauterine adhesions and synechiae resulting from trauma, commonly currettage (<http://www.babymed.com/eponyms-obstetrics-and-gynecology $>$ )

Ballantyne's Syndrome (Ballantyne-Runge syndrome) - Dysmaturity syndrome, placental dysfunction syndrome, postmaturity syndrome, prenatal dystrophy syndrome, prolonged gestation syndrome ( $<$ http://www.babymed.com/eponyms-obstetrics-and-gynecology $>$ )

Bandl's ring - the ring muscle at the border of the uterus corpus and the uterus isthmus, which is developed more pronouncedly during delivery ( $<$ http://www.babymed.com/ eponyms-obstetrics-and-gynecology $>$ )

In the above cases the proper nouns Asherman, Ballantyne and Bandl are connected with common nouns, such as syndroe and ring, making the perception of the phenomenon more understandable. As a result, term-eponyms get the status of a cognitive construction as they denote the specific sphere.

The peculiarities of the nominating processes (both linguistic and extralinguistic) have been studies by cognitive terminologists (Lejchik 2007:123). Many cognitive terminologists think that terms are always in constant movement and they originate in professional speech varieties and are submitted to some changes in the nominative process (Bejsenova 2009:15). Although medical English may give a superficial impression of order and system, it does not possess the qualities in much higher degree than the common speech. In fact, the ceaseless proliferation and endless semantic fusion and differentiation of medical terms have created a variety of problems. The presence in the medical lexicon of four or more names for many anatomic structures, many diseases, and many diagnostic and therepeutic procedures makes it awkward to maintain consistency in medical record-keeping, gathering statistics, billing for medical services, and assigning health insurance benefits, not to mention difficulties in medical and paramedical education and publishing.

Many symptoms, syndroms and terms denoting different diseases include termeponyms. For example. Hippocratic face/facies, Hippocratica (cachexia), Botkin's desease, Filatov's desease, Quinke's edema, Virchow's metastaces, the desease of Hercules.

There are many term-eponyms where the constituent parts include different organs, cells and tissues, e.g. the Fallopian tubes, Golgi cell, etc. 
The analysis has shown that the use of term-eponyms in medical speech is combined with some maneuvers, skills and abilities, e.g. Gunn-Zavanelli-O'Leary maneuver (Zavanelli's maneuver).

Breech presentation may be diagnosed by Leopold's maneuver, vaginal examination, or ultrasound. The point of reference in describing the position of the breech is the sacrum.

Obstetrical maneuver is sometimes used when the baby's head is born but the shoulders are stuck. Other eponyms of this type are: Smellies' manoeuvre (Mauriceau-Levret manipulation), Zavanelli's maneuver, Sim 's position (James Marion Sims).

The term-eponyms Bazedow's disease, Graves' disease, Flajani's disease, Parry's disease, Botkin's disease, Hepatitis A,B are actually very important and play a great role in English medical terminology.

Nowadays there is a tendency to substitute the eponym with a more neutral equivalent, e.g. Bourneville disease - tuberous sclerosis complex, Alice-in-Wonderland syndrome or Todd's syndrome - Lilliputian hallucinations, Lynch syndrome - hereditary nonpolyposis colorectal cancer (HNPCC).

Term-eponyms have some emotional-expressive overtones both positive and negative. For example: Elschnig's pearls, Saint Vitus Dance (<http://www.wisegeek.com/what-issaint-vitus-dance.htm\#did $>$ ).

There are many term-eponyms where the names of two or more doctors are included. These are people who described the symptom, the syndrome or those who found the solution to the problem, e.g. Jackobson-Bechterev-Kempner syndrome, Khenda-ShiulleraKrischena-Zive syndrome.

In theoretical literature eponyms are considered as a variety of conceptual metonymy and many cognitive-linguists have studied this topic.

The research has shown that term-eponyms realize a cognitive function as they indicate the sphere they belong to. In some cases term-eponyms have many equivalents. Eponyms have a scientific-cognitive basis where the cultural aspect is dominant.

\section{Conclusion}

Thus, it can be concluded that medical terminology, including eponyms, is the most important means of communication. Since the very start of development of the language of medicine, Greek and Latin words have been used as terms. Actually they are internationally recognized and helps the scientists all over the world to communicate efficiently. The national and international cognitive-cultural information which is rooted in eponyms becomes a source of knowledge which is of vital importance for the specialists in international communication.

\section{References:}

1. Bejsenova, Zh.S. (2008) K probleme motivirovannosti terminologicheskoi edinici. // Materiali mezh. nauchno-prak. konf.: Sovremennaja termonologija: sostojanie i perspektivi. Astana: KGU. 
2. Bekisheva, E.V. (2007) Formi jazikovoi reprezentacii gnoseologicheskikh kategorii v klinicheskoi terminologii. Avtoref. dis.dokt. fil.nauk / E.V. Bekisheva, Inst. Jazikoznanija RAN, Moskva. Available at: $<$ http://www.referun.com/n/formy-yazykovoy-reprezentatsii-gnoseologicheskih-kategoriy-v-klinicheskoy-terminologii>. [Accessed March 2013]

3. Blejkher, V.M. (1984) Eponimicheskie termini v psikhiatrii, psikhoterapii i medicinskoi psikhologii. Kiev: Vishaya Shkola.

4. Golota, V. Y. (2005) Eponimi v akusherstve i ginekologii. // Medicinskaja literatura. Moskva: Medpresinform.

5. Rilov, J.A. (2006) Imena sobstvennie v evropejskikh jazikakh. Moskva: AST.

6. Lejchik, V.M. (2007) Kognitivnaja lingvistika. // Novie problemi poznanija. N5. Moskva: Vishaya Shkola.

7. (2011) Eponyms in Obstetrics and Gynecology. Available at:

$<$ http://www.babymed.com/eponyms-obstetrics-and-gynecology> [Accessed March 2012]

8. (2010) Contextual Influences in Art \& Design. Available at:

$<$ http://www.wisegeek.com/what-is-saint-vitus-dance.htm\#did $>$ [Accessed June 2012]

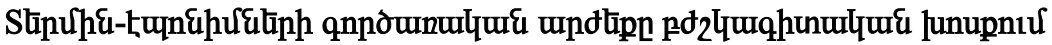

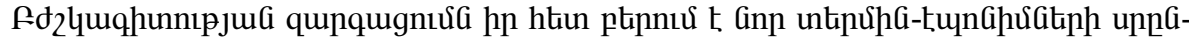

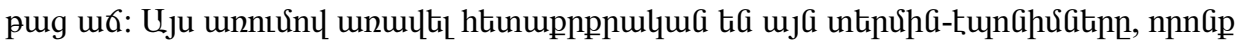

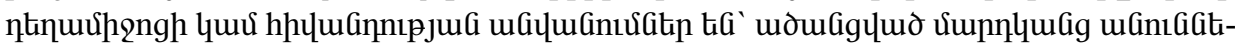

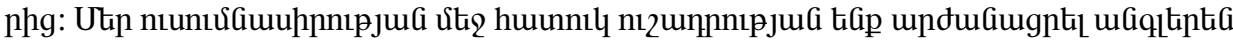

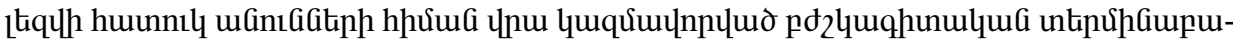

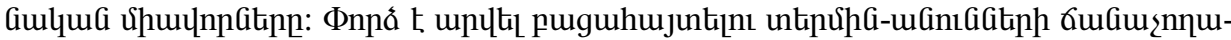

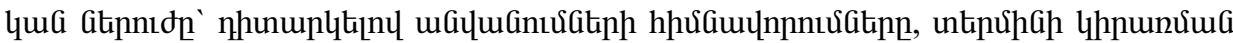

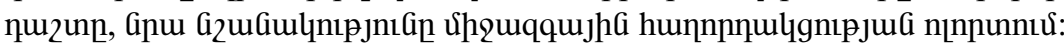

\section{Функциональная значимость терминов-эпонимов в медицинской речи}

В медицинской речи большую роль играют термины-эпонимы. Эпоним - это лексическая единица, в основе которой лежит имя или фамилия человека, впервые обнаружевшего или описавшего ту или иную болезнь или лекарство. В нашем исследовании мы особое внимание уделили терминологическим единицам, в которых имеются английские собственные имена. Национальная, интернационально-культурологическая информация, содержащая в имен собственных, становится источником социального знания, что и облегчает профессиональную коммуникацию. 